532.522

\title{
オリフィス絞りの非定常特 性*
}

\section{1. 緒言}

脈動流の流量測定あるいは流体制御系の設計におい て, 絞り（特にオリフィス）の非定常特性は重要な問 題である。脈動流量の測定においては，平均流量を問 題とし，平方根誤差の考え方にもとづいて，実験結果 を説明することが数多く試みられている(1) (4). これ らの取扱いは，いわゆる準定常流を仮定した一次元流 理論にもとづくものであって，流線が変動しないこと を前提としている. 一方, 流体制御系の解析に際して は, 瞬時特性を問題とする. この場合一次元非定常流 の理諭を適用して非定常項の係数に絞りの等価長さ ${ }^{(2)}$ (4)(6)(7)を用いるのがらつうである(5). しかしこれは一 次元理論にもとづく以上，近似的な取扱いである.こ の上うに絞りを通る非定常流の特性に関する研究は, 現在まだ不十分である。

本研究は, このため, 自由流線理論を適用して, オ リフィスを通る非圧縮性流体の非定常運動を解析し, その結果を実験的に確かめることを目的とする。

自由流線理論を非定常流に適用した研究は，いくつ か行われて括り ${ }^{(9)(10)}$ ，また数值解法についての研究も ある(11)。しかし，それを絞りを通る非定常流に適用し た研究はないと思われるし, 本研究の手法は従来のも のと相違している.

\section{2. 記 号}

本論文に用いる主な記号は，つぎのと拈りである.

$$
\begin{aligned}
b & : \text { 絞りの幅 }=\bar{b} L=(\pi+2) L \\
c & : \text { 瞬時流量係数, 式 }(35) \\
c_{c} & : \text { 縮流係数 } \\
d & : \text { オリィイ径 } \\
D & : \text { 管内径 } \\
F & : \text { 複素ポテンシャル }=U L \bar{F} \\
i & : \text { 虚数単位 } \\
k & : \text { 式 }(38) \text { に打る係数 } \\
L & : \text { 代表長さ }
\end{aligned}
$$

* 昭和 49 年 9 月. 2 日 東海支部浜松地方講演会において論文講 演として挐演，原稿受付 昭和 49 年 5 月 7 日。

** 正員, 横浜国立大学工学部（横浜市南区大岡 2-31-1）.

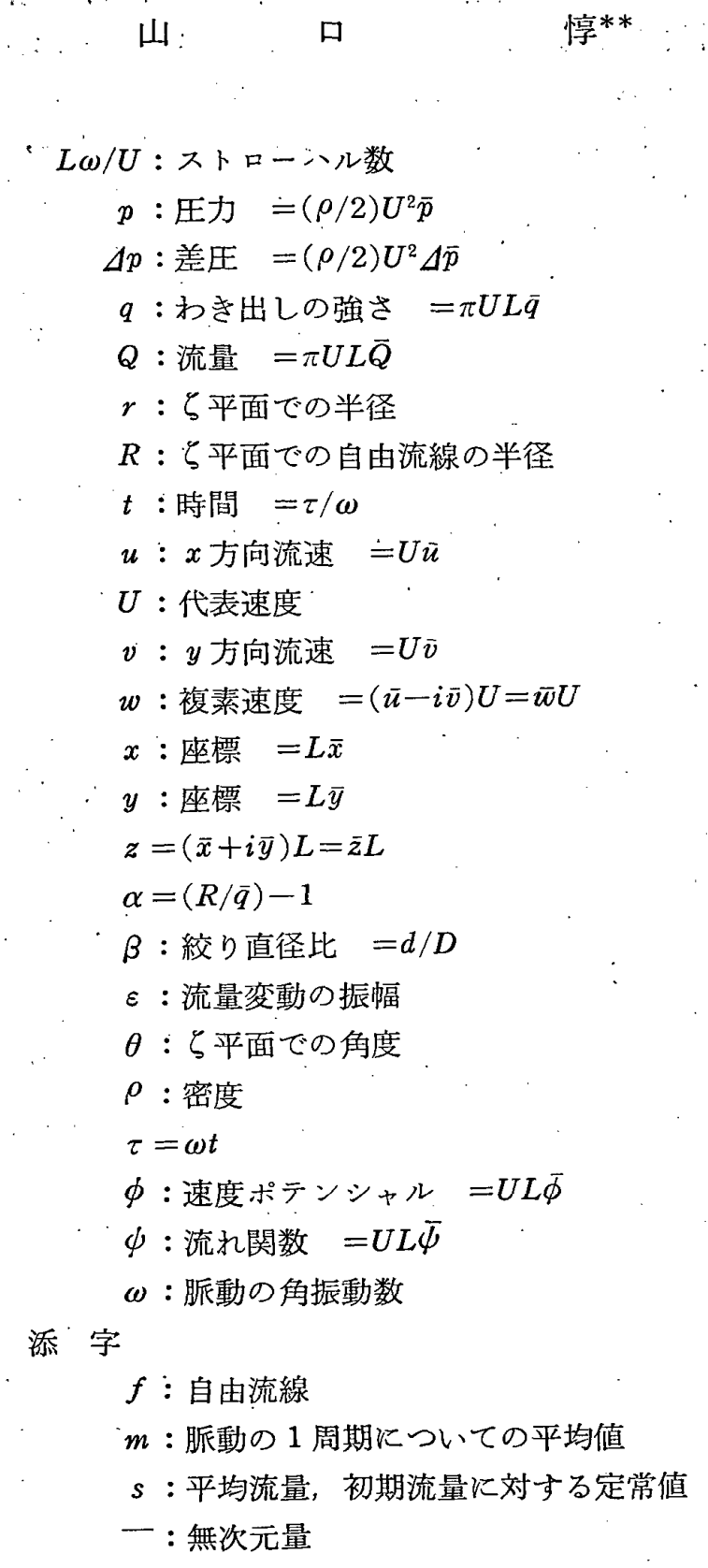

\section{3. 理 論 解 析}

絞りを通る流れが，二次元らずなし流れであるとす る. 速度ポテンシャル $\bar{\phi}(\bar{x}, \bar{y}, \tau)$, 流れ関数 $\bar{\psi}(\bar{x}, \bar{y}$, て）は，非圧縮性流体を仮定すれば，ラプラスの方程式 を満たす。

非定常流に拡張されたベルヌーイ式より，重力の影 響を無視して

$$
2 \frac{L \omega}{U} \frac{\partial \bar{\phi}}{\partial \tau}+(\nabla \bar{\phi})^{2}+\bar{p}=2 \bar{H}
$$


が成り立つ. ただし $\bar{H}=\bar{H}(\tau)$ は積分定数. 自由流線 上では, $\bar{p}=0$ より

$$
2 \frac{L \omega}{U} \frac{\partial \bar{\phi}}{\partial \tau}+(\nabla \bar{\phi})^{2}=2 \bar{H} \text {. }
$$

が成り立つ.

境界条件として，（i）较りの上流側の面上（因 1 の $\mathrm{AB}$ 上) で

$$
\frac{\partial \bar{\phi}}{\partial \bar{x}}=\frac{\partial \bar{\psi}}{\partial \bar{y}}=0
$$

(ii ） $x$ 軸に対して上下対称であること，打よび（iii） 自由流線が

$$
G(\bar{x}, \bar{y}, \tau)=0
$$

で与兄られるとすると，次式が成り立たねばならない。

$$
\frac{L \omega}{U} \frac{\partial G}{\partial \tau}+\bar{u} \frac{\partial G}{\partial \bar{x}}+\bar{v} \frac{\partial G}{\partial \bar{y}}=0
$$

条件（iii）は，自由流線が積分定数を $g(\tau)$ として， $\bar{\psi}(\bar{x}, \bar{y}, \tau)=g(\tau)$ と与えられることから，近似的に満 たされる*.

さて、この流れをホドグラフ面を用いて解析する(12). ただし，自由流線上の流速は，ホドグラフ上でだ円で 表されるものと仮定する.すなわち図 1 の流れが，対 称性を考慮すると図 2 のよ.5に，四半分のだ円内の流 れで与えられるとする. 絞りを通る定常流に和いて は，ボドグラフ上の自由流線は円弧となるから，この 取扱いは，非定常性の影響があまり強くない場合を考 えることになるう。

物理面（ $z$ 面）とホドグラフ面（ $w$ 面）との対応は,

$$
\bar{z}=\int \frac{d \bar{F}}{\bar{w}}
$$

で与えられる，Rを未知のパラメータとする関数

$$
\bar{w}=R^{2} / \Omega
$$

に上り， $\bar{w}$ 面の流れを $\Omega$ 面に写像する。.これを未知 のパラメータ $a\left(R^{2}>|a|\right)$ を用いて

$$
\Omega=T+(a / T)
$$

により， $T$ 面に写像する.さらに

$$
T=R^{2} / \zeta
$$

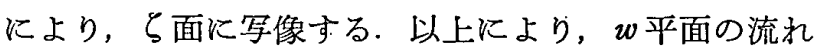

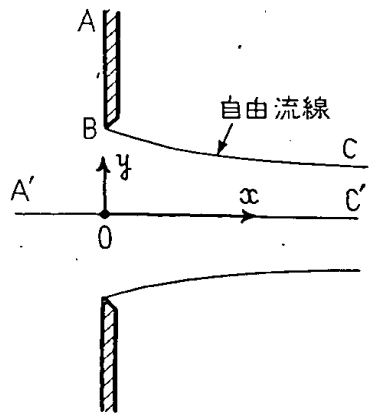

図 $1 \quad z$ 平面

近似の程度は付图 1 に示すよ.5に良好である
は $\zeta$ 平面の半径 $R$ である四分円内の流れに写像された ことになる（図 3 )。ここに $R, a$ は共洔間の関数で あるが，写像理諭に扔いて時間は単にパラメータとし て含まれるために，この取扱いが可能となる.

ら平面に括ける流れは，鏡像の原理にもとづいて原 点にわき出し，実軸上 $\pm R$ に吸込みを置いた場合に 相当する：ここで差異を明らかにするため，定常流に おける基準の取り方を採用する，すなわち；脈動流の 場合，その平均流量に対応する縮流部流速を 1 と選び, 過渡的な流れの場合，その初期流量に対応する縮流部 流速を 1 と選ぶ. したがって，この基準流量に対し $R$ $=1$ ，絞りを通過する流量は $\pi ＼mathrm{~ ， な た 無 次 元 化 さ れ た ~}$ 絞りの幅は $\pi+2$ となる.

以上により平面に拈ける複素ポテンシャルは,

$$
\vec{F}=\bar{q}[-\ln (\zeta+R)(\zeta-R)+\ln \zeta]
$$

で与えられ，自由流線は

$$
\zeta=\operatorname{Re}^{i \theta} \quad(0 \leqq \theta \leqq \pi / 2)
$$

で与兄られる.

$w$ 平面と $\zeta$ 平面の間には，式 $(7) \sim(9)$ より

$$
\bar{w}=R^{4} \zeta /\left(R^{4}+a \zeta^{2}\right)
$$

が成り立つから，式（6)，(10)，(12）より

$$
\begin{aligned}
\bar{z} & =\bar{q}\left[-\frac{1}{\zeta}+\frac{1}{R} \ln \frac{\zeta+R}{\zeta-R}\right] \\
& +\bar{q} \frac{a}{R^{4}}\left[-\zeta+R \ln \frac{\zeta+R}{\zeta-R}\right]+\bar{z}_{0}
\end{aligned}
$$

をうる.ただし $\bar{z}_{0}$ は積分定数.

$$
\zeta=r e^{i \theta}
$$

を式（13）に代入し，実数部と虚数部に分けると，

$$
\begin{aligned}
\bar{x} & =\bar{q}\left[-\frac{\cos \theta}{r}+\frac{1}{2 R} \ln \frac{R^{2}+r^{2}+2 r R \cos \theta}{R^{2}+r^{2}-2 r R \cos \theta}\right] \\
& +\bar{q} \frac{a}{R^{4}}\left[-r \cos \theta+\frac{R}{2} \ln \frac{R^{2}+r^{2}+2 r R \cos \theta}{R^{2}+r^{2}-2 r R \cos \theta}\right]+\bar{x}_{0}
\end{aligned}
$$

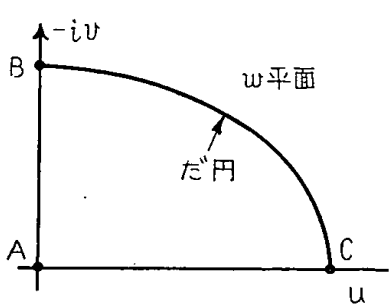

図 2 ホドグラフ面

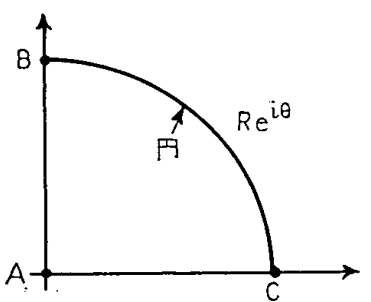

図 $3 \zeta$ 平面 


$$
\begin{aligned}
\bar{y} & =\bar{q}\left[\frac{\sin \theta}{r}+\frac{1}{R} \tan ^{-1} \frac{2 r R \sin \theta}{R^{2}-r^{2}}\right] \\
& +\bar{q} \frac{a}{R^{4}}\left[-r \sin \theta+R \tan ^{-1} \frac{2 r R \sin \theta}{R^{2}-r^{2}}\right]+\bar{y}_{0}
\end{aligned}
$$

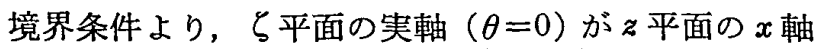
上の流れに対応することから，式(16)に沶いて $\theta=0$ としたとき， $\bar{y}=0$ でなければならない.すなおち $\bar{y}_{0}$ $=0$. また虚軸 $(\theta=\pi / 2)$ が $y$ 軸上の流れ（図 1 のB 上の流れ）に対応することから, 式 (15) に和いて $\theta=\pi / 2$ としたとき， $\bar{x}=0$ でなければならないすすな わち $\bar{x}_{0}=0$.

自由流線は, 式 (15),（16）で $r=R$ としたるので 与えられ,

$$
\begin{aligned}
& \bar{x}_{f}=\frac{\bar{q}}{R}\left[-\cos \theta+\frac{1}{2} \ln \frac{1+\cos \theta}{1-\cos \theta}\right]\left(1+\frac{a}{R^{2}}\right) \\
& \cdots \cdots \cdots \cdots(17) \\
& \bar{y}_{f}=\frac{\bar{q}}{R}\left(\frac{\pi}{2}+\sin \theta\right)+\bar{q} \frac{a}{R^{3}}\left(\frac{\pi}{2}-\sin \theta\right)
\end{aligned}
$$

となる。 $z$ 平面に括いて，自由流線は，絞りの縁（図 1 のB点) から描かれるから， $\theta=\pi / 2$ に扎いて $\bar{x}_{f}=$ $0, \bar{y}_{f}=(\pi / 2)+1$ とならなければならない。 したが $\sim \tau$

$$
\frac{a}{R^{2}}=\frac{\pi+2}{\pi-2}\left(\frac{R}{\bar{q}}-1\right)
$$

が定なる。

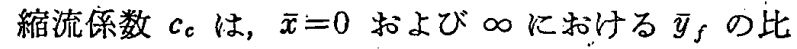
として定義され,

$$
c_{c}=\frac{\pi}{\pi-2}-\frac{4 \pi}{(\pi+2)(\pi-2)} \cdot \frac{\bar{q}}{R}
$$

となる

自由流線上の流速は，式（12）に式（14）を代入し, $r=R$ と和けば求まり，

$$
\left.\begin{array}{l}
\bar{u}=R^{3}\left(R^{2}+a\right) \cos \theta /\left(R^{4}+2 a R^{2} \cos 2 \theta+a^{2}\right) \\
\bar{v}=-R^{3}\left(R^{2}-a\right) \sin \theta /\left(R^{4}+2 a R^{2} \cos 2 \theta+a^{2}\right)
\end{array}\right\}
$$

となる、 $\bar{x} \rightarrow \infty$ に拉る $\bar{x}$ 方向流速 $\bar{u}_{\infty}$ は，上式で $\theta=0$ とすることより

$$
\bar{u}_{\infty}=R^{3} /\left(R^{2}+a\right)
$$

となり，流量は

$$
\bar{Q}=2 \bar{u}_{\infty} \bar{y}_{f \infty} / \pi=\bar{q}
$$

となる.

つぎに自由流線に対するエネルギ式, '式 (2)につい て検討する.式 (21) より

$$
(\nabla \bar{\phi})^{2}=\bar{u}^{2}+\bar{v}^{2}=R^{6} /\left(R^{4}+2 a R^{2} \cos 2 \theta+a^{2}\right)
$$

一方，式（10）をてで微分すると

$$
\begin{aligned}
\dot{\bar{F}} & =\dot{\bar{q}}[\ln \zeta-\ln (\zeta-R)(\zeta+R)] \\
& +\dot{\bar{q}} \dot{R}\left[\frac{1}{\zeta-R}-\frac{1}{\zeta+R}\right]
\end{aligned}
$$

をうる.式 (11) を代入し，その実数部をとると

$$
\dot{\bar{\phi}}=-\dot{q} \ln (2 R \sin \theta)-\bar{q} \dot{R} / R
$$

をらる. 以上を式 (2) に代入すると,

$$
\begin{aligned}
\frac{U}{2 L \omega} & R^{2}-\frac{U}{\dot{L} \omega} \bar{H}\left(1+\frac{a^{2}}{R^{4}}\right)-\left(1+\frac{a^{2}}{R^{4}}\right)\left[\dot{\bar{q}} \ln (2 R)+\bar{q} \frac{\dot{R}}{R}\right]-2 \frac{U}{L \omega} \dot{\bar{H}} \frac{a}{R^{2}} \cos 2 \theta \\
& -\dot{\bar{q}}\left(1+\frac{a^{2}}{R^{4}}\right) \ln (\sin \theta)-2 \frac{a}{R^{2}} \cos 2 \theta\left[\dot{\bar{q}} \ln (2 R \sin \theta)+\bar{q} \frac{\dot{R}}{R}\right]=0 \ldots \ldots \ldots \ldots \ldots . . .
\end{aligned}
$$

をらる、いま上式に拈いて，かりに $R=\bar{q}$ と扰く

$$
\frac{U}{2 L \omega} R^{2}-\frac{U}{L \omega} \bar{H}-[\dot{R} \ln (2 R)+\dot{R}]-\dot{R} \ln (\sin \theta)=0
$$

となる. $R, \bar{H}$ は $\theta$ の関数ではないから，L $L / U \neq 0$ では，すなわら非定常流では， $R=\bar{q}$ の関係は成り立たな い.しかし，比 $R / \bar{q}$ は 1 かずれるとしてる，その差はあまり大きくないと予想される.したがって

$$
R / \bar{q}=1+\alpha \quad(|\alpha| \ll 1)
$$

として，式（24）を書さ直す.

$$
\begin{aligned}
& \frac{U}{2 L \omega}(1+\alpha)^{2} \bar{q}^{2}-\frac{U}{L \omega} \bar{H}\left[1+\left(\frac{\pi+2}{\pi-2}\right)^{2} \alpha^{2}\right]-\left[1+\left(\frac{\pi+2}{\pi-2}\right)^{2} \alpha^{2}\right]\left[\dot{\bar{q}}+\dot{\bar{q}} \ln (2 R)+\frac{\dot{\alpha}}{1+\alpha} \bar{q}\right] \\
& -2 \frac{\pi+2}{\pi-2} \alpha \bar{H} \frac{U}{L \omega} \Theta_{1}-2 \frac{\pi+2}{\pi-2} \bar{q} \frac{\alpha \dot{\alpha}}{1+\alpha} \Theta_{1}-\dot{\bar{q}} \Theta_{2}-2 \frac{\pi+2}{\pi-2} \alpha \dot{\bar{q}} \Theta_{3}-\left(\frac{\pi+2}{\pi-2}\right)^{2} \alpha^{2} \dot{\bar{q}} \Theta_{2}=0
\end{aligned}
$$

$こ こ に$

$$
\Theta_{1}=\cos 2 \theta, \quad \Theta_{2}=\ln (\sin \theta), \quad \Theta_{3}=\cos 2 \theta[1+\ln (2 R)+\ln (\sin \theta)] \doteqdot \cos 2 \theta[1+\ln 2+\ln (\sin \theta)]
$$

式（26）が $\theta=0 \sim \pi / 2$ の範囲で， $\theta$ にかかわらず成り立つためには，式（26）の $\theta$ を含を係数を $\theta$ のべき級 数に展開し， $\theta$ にいて整理したときその $\theta$ の係数がすべて0であればよい，しかし，未知量と方程式の数の関 
係から、この目的に使える条件は一つであり，このため近似的な取扱いをする.すなわら式（26）の両辺に $\theta$ を 乗じ， $\theta \Theta_{i}(i=1 \sim 3)$ で与えられる係数を，定数 $\beta_{i}, \delta_{i}$ を用いて

$$
\theta \Theta_{i}=\beta_{i} \theta+\delta_{i} \theta^{2}(1-0.34 \theta)
$$

の形に近似する. $\beta_{i}, \delta_{i}$ は最良近似（ミニマックス近似）にもとついて決定すると，つぎの值となる.

$$
\beta_{1}=2.50, \quad \beta_{2}=-1.97, \quad \beta_{3}=3.30, \quad \delta_{1}=-4.65, \quad \delta_{2}=2.72, \quad \delta_{3}=-6.50
$$

この近似の最大誤差は，図 4 に示すように，それぞれの $\left|\theta \Theta_{i}\right|$ の最大值の $10 \sim 16 \%$ に達している.

式（28）を式（26）に代入して， $\theta, \theta^{2}$ の係数を等置することにより， $\alpha$ と $\bar{H}$ に対する関係が定まる。すなわ ち， $\alpha$ は四次式

$$
\begin{aligned}
& \left(\frac{\pi+2}{\pi-2}\right)^{4} \delta_{2} \dot{\bar{q}} \alpha^{4}+\frac{\pi+2}{\pi-2}\left[\frac{U}{L \omega} \delta_{1} \bar{q}^{2}+2\left(\frac{\pi+2}{\pi-2}\right)^{2} \dot{q}\left\{\delta_{3}+\beta_{1} \delta_{2}-\beta_{2} \delta_{1}-\delta_{1}(1+\ln 2 R)\right\}\right] \alpha^{3} \\
& \quad+2 \frac{\pi+2}{\pi-2}\left[\frac{U}{L \omega} \delta_{1} \bar{q}^{2}+\frac{\pi+2}{\pi-2} \dot{\bar{q}}\left(\delta_{2}+2 \beta_{1} \delta_{3}-2 \beta_{3} \delta_{1}\right)\right] \alpha^{2} \\
& \quad+\frac{\pi+2}{\pi-2}\left[\frac{U}{L \omega} \delta_{1} \bar{q}^{2}+2 \dot{\bar{q}}\left\{\delta_{3}+\beta_{1} \delta_{2}-\beta_{2} \delta_{1}-\delta_{1}(1+\ln 2 R)\right\}\right] \alpha+\delta_{2} \dot{\bar{q}}=0
\end{aligned}
$$

より, $\bar{H}$ は

$$
\frac{U}{L \omega} \bar{H}=-\frac{\left[\begin{array}{c}
-\frac{U}{2 L \omega}(1+\alpha)^{2} \bar{q}^{2}+\left[1+\left(\frac{\pi+2}{\pi-2}\right)^{2} \alpha^{2}\right]\left[\dot{\bar{q}}+\dot{\bar{q}} \ln 2 R+\frac{\dot{\alpha}}{1+\alpha} \bar{q}\right. \\
+\beta_{2} \dot{\bar{q}}+2 \frac{\pi+2}{\pi-2} \beta_{1} \bar{q} \frac{\alpha \dot{\alpha}}{1+\alpha}+2 \frac{\pi+2}{\pi-2} \beta_{3} \dot{\bar{q}} \alpha+\left(\frac{\pi+2}{\pi-2}\right)^{2} \beta_{2} \dot{\bar{q}} \alpha^{2}
\end{array}\right]}{1+2 \frac{\pi+2}{\pi-2} \beta_{1} \alpha+\left(\frac{\pi+2}{\pi-2}\right)^{2} \alpha^{2}}
$$

より定まる.

つぎに， $\bar{x}$ 軸上 $\bar{x}=\bar{x}_{p}$ に括ける圧力を求める. 式 (15) より， $\bar{x}_{p}$ と $r$ の関係が定まるが， $(r / R)^{3}$ 以上 が省略可能であれば,

$$
r=\frac{\left(\bar{x}_{p} / \bar{q}\right)+\sqrt{\left(\bar{x}_{p} / \bar{q}\right)^{2}+4\left\{\left(2 / R^{2}\right)+\left(a / R^{4}\right)\right\}}}{\left(4 / R^{2}\right)+\left(2 a / R^{4}\right)}
$$

となる. $\bar{x}=\bar{x}_{p}$ に打ける速度から

$$
(\nabla \bar{\phi})^{2}=\left(\frac{r R^{4}}{R^{4}+a r^{2}}\right)^{2} \fallingdotseq r^{2}\left(1-2 \frac{a}{R^{2}} \frac{r^{2}}{R^{2}}\right)
$$

また

$$
\frac{\partial \bar{\phi}}{\partial \tau} \fallingdotseq \dot{\bar{q}}\left[\ln r-2 \ln R+\frac{r^{2}}{R^{2}}\right]-2 \bar{q} \frac{\dot{R}}{R}\left(1+\frac{r^{2}}{R^{2}}\right)
$$

が成り立つ. 以上を式 (1) に代入すれば, $\bar{x}=\bar{x}, \bar{y}=0$ に拈ける王力が求まる。

流量係数については，ある瞬間に打ける流量と圧力 差により定義される瞬時流量係数を用いる。

$$
c=c_{s} \bar{q} \sqrt{\Delta \bar{p}_{s} / \Delta \bar{p}}
$$

以上の結果について数値例により検討を加える.た だし非定常性の絞り特性に及ぼす影響を明確にするた め, 定常流の場合との比の形で表示することとする. またこれらの数值例に拀いて，特に記さないかぎり

$$
\bar{q}=1-\varepsilon \cos \tau, \quad L \omega / U=0.1
$$

としている. 図 5 は脈動の 1 周期についての $\alpha$ の変化 を示す．図 6 は縮流係数比 $c_{c} / c_{c s}$ を示す. $c_{c} / c_{c s}$ は $\alpha$
と同様の変化をし，流量の増加区間で大きく，減少区 間で小さくなる，その平均值は $\varepsilon$ の増大につれ; わず

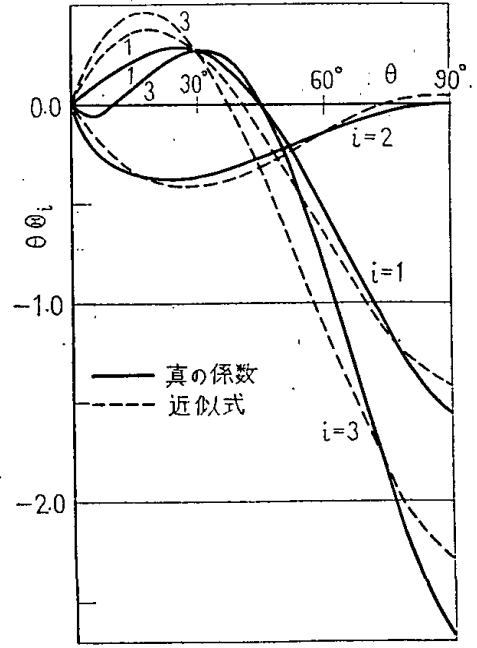

図 4 近似式の精度

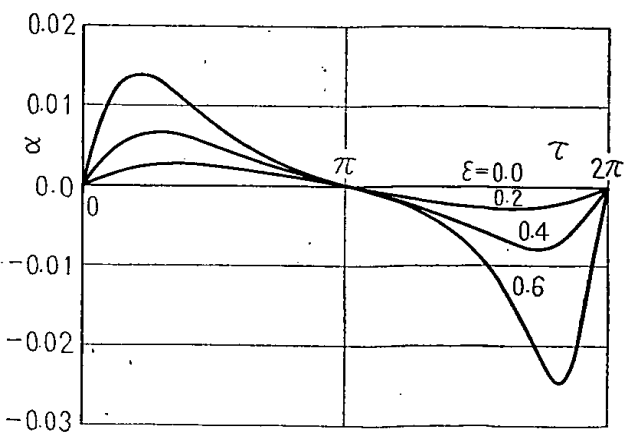

図 $5 \alpha=(R / \bar{q})-1$ 
かずっではあるが減少する，図 7 は $\dot{c}_{c} / c_{c s}$ の過渡応答 についての数值例であり, 流量を

$$
\left.\begin{array}{l}
\tau \leqq 0 \cdots \cdots \cdots \cdots \cdots \cdots \cdots \cdot \bar{q}=1 \\
0<\tau \leqq \pi / 2 \cdots \cdots \cdots \cdot \bar{q}=1+\varepsilon \sin \tau \\
\tau>\pi / 2 \cdots \cdots \cdots \cdots \cdots \cdot \bar{q}=1+\varepsilon
\end{array}\right\}
$$

と変化させている. $0<\tau \leqq \pi / 2$ に执いて， $\bar{q}$ の增大す る場合 $c_{c}>c_{c s}$ であり，減少する場合 $c_{c}<c_{c s}$ となる のは，絞りに打ける損失が前者では定常流の場合より 減少し，後者では逆に増大することを示しており，こ のことは Dailey ら ${ }^{(13)}$ の実験結果と一致する.

舷り前後の差压比の変化を図 8 亿示す，ただし，下 流側圧力としては自由流線上の圧力（ $\bar{p}=0 ）$ を用い， 上流側に対しては; “式(33)，・(34) よりわかるように, $\bar{x}_{p}$ が関係するため，

$$
\bar{x}_{p}=-k \bar{b} / 2 \quad(k=1 \sim 4)
$$

としている. 図には $k=1 ４$ の場合を示しているが，

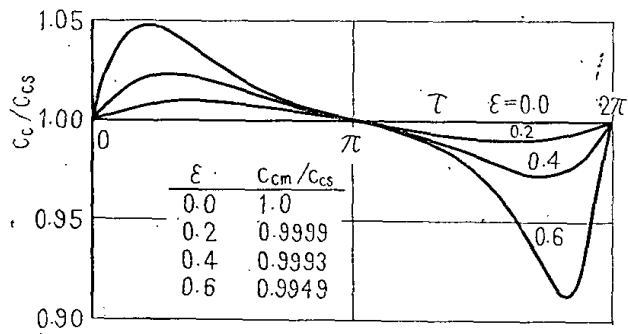

図 6 縮流係数比

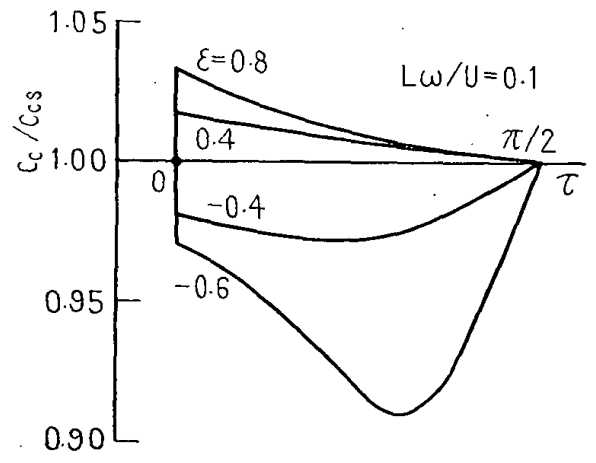

図 7 縮流係数比の過渡応答

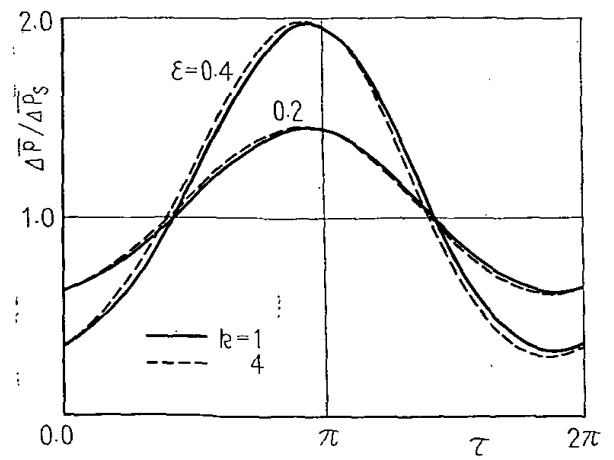

図 8 差压比（压力测定位置の影響） $k=2,3$ の場合は，この中間の值をとる。なお $\Delta \bar{p}_{s}$ は

$$
\Delta \bar{p}_{s}=1-\left\{\left(\bar{x}_{p}+\sqrt{\bar{x}_{p}{ }^{2}+8}\right)^{2} / 16\right\}
$$

で与えられる。

园 9〜11 亿瞬時流量倸数比 $c / c_{s}$ を示す，流量の增 大する区間では $c<c_{s}$ ，減少する区間では $c>c s$ とな る.これは，式（35）に定義した瞬時流量係数には， 絞り前後の流体を時間的に加速あるいは減速するため に要する圧力が含まれているためである．図 9 は压力 測定位置の影響を示し， $k$ の大きい注ど，すなわち $\left|\bar{x}_{p}\right|$ の大さい注ど絞り前後に考慮される流体質量が大 きいため， $c / c s$ の変化が大きくなる．またその平均值 も大きくなる，図10 はストローハル数の，図 11 は 脈動の振幅の影響を示す。これらの増大につれ流量係 数の変化が急激になり，平均值も大きくなることがが かる.

図 12 飞差王比の平均値と脈動流量の振幅との関係 を示す. $\Delta \bar{p}_{m} / \Delta \bar{p}_{s}$ は, 脈動流量の測定に抽いて, 平方

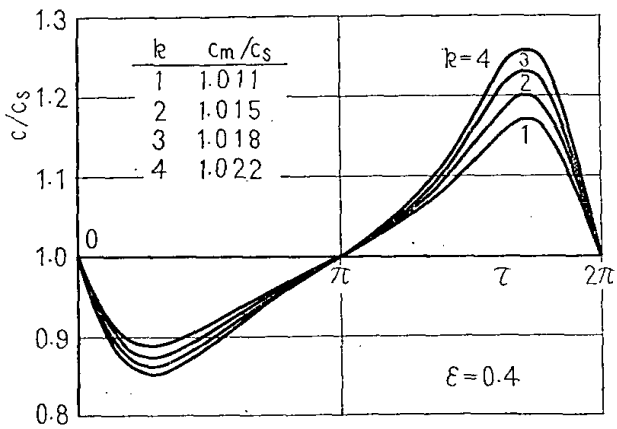

図 9 瞬時流量係数比（圧力測定位置の影響）

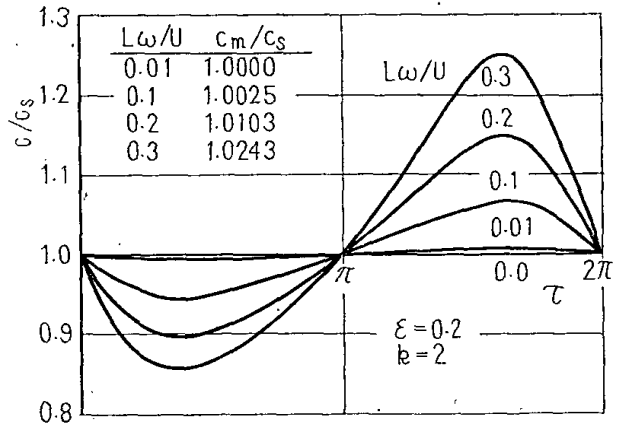

図 10 瞬時流量係数比（ストローハル数の影響）

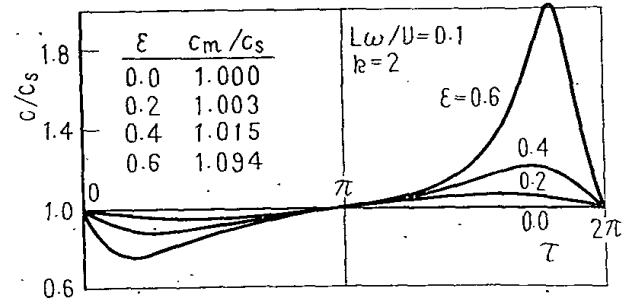

図 $11 \cdot$ 瞬時流量俰数比（脈動振幅の影響） 
根言美に対する修正係数として用いられ，その場合

$$
\Delta \bar{p}_{m} / \Delta \bar{p}_{s}=1+0.5 \varepsilon^{2}
$$

となる(2)。本理論に和いても， $L \omega / U \leqq 1$ の範囲でスト ローハル数の影響は汷とんど認められず, $\Delta \bar{p}_{m} / \Delta \bar{p}_{s}$ の 值も式 (40) に浪淁一致する. 図 13 は差圧比の平方 根の平均値と脈動流量の振幅との関係を示す。この場 合ストローハル数の影響が著しく，また㕳示の值より 大きい $\varepsilon$ にいては解が求まらない。脈動流量の計測 に関して, Schultz-Grunow ${ }^{(8)}$ は, 実験結果にもとゔ き，ストローハル数 $d(\omega / 2 \pi) / u$ が $1 / 510$ 以下であれ ば，流れを準定常流とみなせるとしている（ここにu : 管平均流速).しかし図 13 の結果からは, さらに大 さなストローハル数でも, 非定常性の影響は無視でき

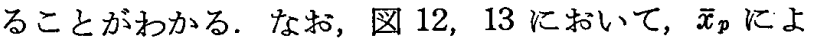
る差（ $k=1 \sim 4$ の範囲で）はほとんどない.

\section{4. 実験}

本理論解析は二次元流を対象としているが，非定常 性の影響は軸対称流でもあまり変わらないと考えられ ること，また実用上問題となるのはほとえどが軸対称 流であることから，実験は JIS Z 8762 に規定される オリフィスについて行うこととした. たたしオりフィ スは図 14 に示すように管路末端に設けた.

供試オリフィスは $\beta=0.45, c_{s}=0.628$ および $\beta=$ $0.55, c_{s}=0.643$ の 2 種類であり, これらの流量係数 は後述の方法により，熱線流速計により求めた值であ る. 平均流量测定用オりフィスは $\beta=0.40$ であり，

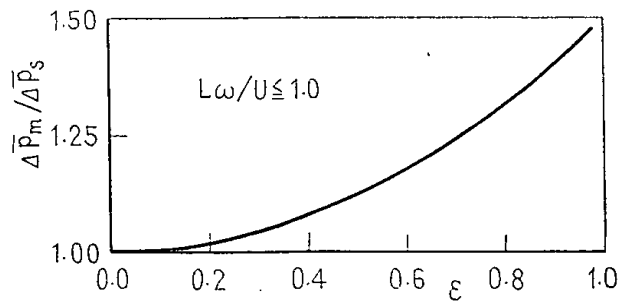

図 12 差圧比の平均値

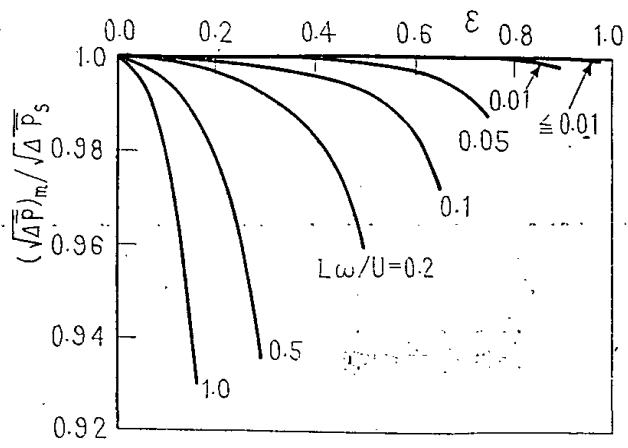

図 13 差圧比の平方根の平均値
圧力の測定には，いずれも縮流タップ（供試オリフィ スについては上流側のみ）を用いた。

脈動の発生には，電気一油圧サ一ボ弁を用いて:空気 圧シリンダのピストンを歌動し，流量がほぼ正弦波状 に変化するようにした．また整流物よび脈動の上流へ の伝ぱを防止する目的で 2 個の空気箱を設けた，空気 箱(1)には整流用ノズルを，空気箱(2)では管の先端にフ ィルタエレ゙ント（粒度 5 および 10 ミクロン）を付け た.な特，定常流に対して管出口部（供試オリフィス 取付け部）の速度分布が，水平和よび垂直な直径上に おいて，1/7 乗法則に一致することを確かめた。

圧力の測定はひずみ压力計（容量 $20 \mathrm{~g} / \mathrm{cm}^{2}$, 共振 周波数 $500 \mathrm{~Hz}$ ) により，流速の測定は定温度形熱線 流速計 (X形，I 形プローブ; タングステン線直径 5 ミクロン, 有効部長さ約 $1 \mathrm{~mm}$ ) により行い, 増幅器 を介してビジグラフに記録した.な扗力計と流速計 の検定は定常状態について行ったが，流速計について は各実験ごとに検定した。

流量の算出は, つぎのよらにして行った. オリフィ ス孔出口の流路面積を円環状に $n$ 等分し（ $\beta=0.45$ で は $n=7, \beta=0.55$ では $n=10)$ ，さらに各区分面積を 2 等分する半径位置に括いて軸力向流速を测定する. ただし管中央の区分に対しては，オリフィス孔中心に 括ける流速を用いる。したがって，直径上での流速測 定点は $2 n-1$ 箇所々なる. ついで同一半径上の流速 を平均し，面積を乘じて加えることにより，流量を求 める.このようにして求めた流量は, 平均流測定用才 リフィスによる值に対しほぼ $2 \%$ 以内の差で一致した (非定常流の場合には, 平均流量に対する比較).

いくつかの実験の状況を表 1 に示寸，表に打いて， $\varepsilon_{1} \sim \varepsilon_{4}$ は上記の方法によって求めた流量を

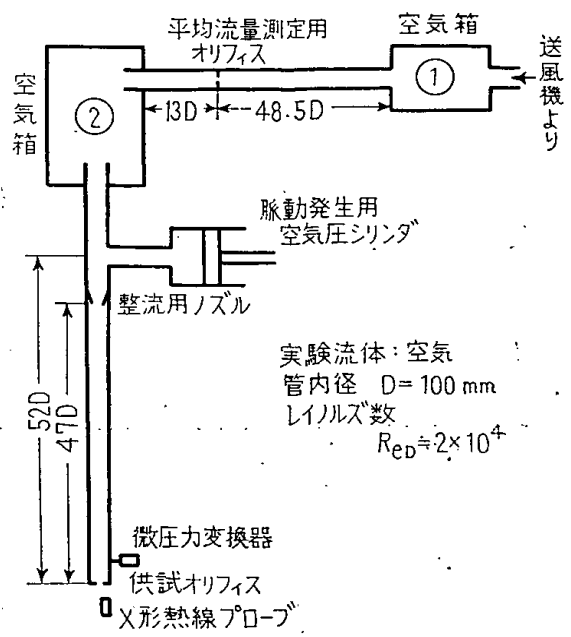

図 14 , 実験装置説明図 
$Q=Q_{m}\left(1+\varepsilon_{1} \cos \tau+\varepsilon_{2} \cos 2 \tau+\varepsilon_{3} \sin \tau+\varepsilon_{4} \sin 2 \tau\right)$

と表したときの振幅であり,ストローハル数 $L \omega / U$ に 打ける代表速度は，縮流部流速，すなわら

$$
U=\left(\frac{Q_{m}}{c_{c s}}\right) / \cdot \frac{\pi}{4} d^{2}
$$

より，代表長さ $L$ は

$$
L=d /(2+\pi)
$$

より求めた.ただし $b=d$ である.

\section{5. 考察}

図 15 に差圧比についての，図 16 亿瞬時流量係数 についての理論と実験との比較を示す，理論値は，表 1 に示す流量とストロー八ル数とから， $k=2$ として計 算した値であり，実験值は 1 周期を 12 等分した間隔 に挌ける値を示してある。かなり良好な一致が得られ ている. 表 1 に示す他の場合についても，ほぼ同様の 一致が得られている. 平均値についての理論と実験と の比較を表 2 に示す。特に $(\sqrt{\Delta \bar{p}})_{m} / \sqrt{\Delta \bar{p}_{m}}$ について は，流量の測定誤差が影響を及ぼさないような比較と なるため，理論と実験との一致はきわめてよい。

平均流量を求める目的には，'平均流量に対して定義 される流量係数を用いるのが便利である。すなわち， 平均流量と差压の平方根の平均値より定義される流量 係数は，

$$
c_{\sqrt{p}}=c_{s} \sqrt{\Delta \bar{p}_{s}} /(\sqrt{\overline{\Delta \bar{p}}})_{m}
$$

平均流量と平均差圧の平方根より定義される流量係数

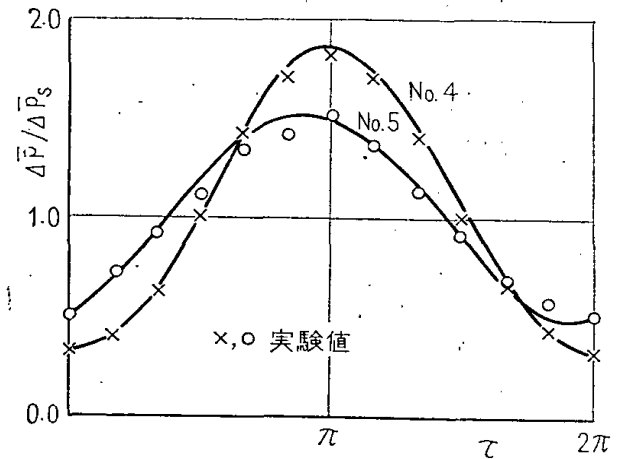

図 15 理論と実験との比較（差圧比）
は,

$$
c_{p}=c_{s} \sqrt{\Delta \bar{p}_{s}} / \sqrt{\Delta \bar{p}_{m}}
$$

となる。両式より

$$
c_{p} / c \sqrt{p}=(\sqrt{\Delta \bar{p}})_{m} / \sqrt{\Delta \bar{p}_{m}}
$$

となる. 式 (44)，（45）に扣いて，定常流の流量係数 に対する補正は差圧比の形で与えられ，図 12，13 に 示す值が利用できる。

一次元非定常理論にもとづくと，絞りの差圧は流量 係数が定常流と同一であることを仮定して

$$
\frac{\Delta p}{\rho}=\frac{1}{2}\left(\frac{Q}{c_{s} A}\right)^{2}+\frac{l_{B}}{A} \frac{d Q}{d t}
$$

で与えられる．ただし $A$ : 絞り面積, $l_{\theta}$ : 絞りの等価 長さであり，厚さlのオリフィスの場合

$$
l_{e}=l+d[(8 / 3 \pi)-1.06 \beta]
$$

となる(2)(4). この取扱いについて，本理論解析と数値 的に比較する.このため, 式 (48)に扎いて, $\beta=l=0$ とし, $d=b$ とする. したがうて式 (47) は

$$
\frac{\Delta \bar{p}}{\Delta \bar{p}_{s}}=\bar{q}^{2}+\frac{16}{3}-\frac{L \omega}{U} \frac{d \bar{q}}{d \tau}
$$

\begin{tabular}{|c|c|c|c|c|c|c|c|c|c|}
\hline No. & $\beta$ & $\begin{array}{c}\omega / 2 \pi \\
\mathrm{Hz}\end{array}$ & $\begin{array}{c}\Delta p_{s} \\
\operatorname{cmAq}\end{array}$ & $L \omega / U$ & $\begin{array}{l}Q_{m} \\
l / \mathrm{s}\end{array}$ & $\varepsilon_{1}$ & $\varepsilon_{2}^{\prime}$ & $\varepsilon_{3}$ & $\varepsilon_{4}$ \\
\hline 1 & 0.45 & 10 & 3.45 & $2.29 \times 10^{-2}$ & 23.3 & -0.362 & -0.022 & 0.016 & 0.004 \\
\hline 2 & $" 1$ & 5 & 3.29 & $1.17 "$ & 22.9 & -0.236 & -0.005 & 0.010 & 0.006 \\
\hline 3 & " & 30 & 3.42 & $6.91 "$ & 23.2 & -0.257 & -0.017 & 0.007 & -0.002 \\
\hline 4 & 0.55 & 10 & 1.30 & $4.44 "$ & 22.0 & -0.383 & -0.017 & -0.061 & -0.024 \\
\hline 5 & $"$ & 30 & 1.37 & $1.30 \times 10^{-1}$ & 22.5 & -0.243 & -0.023 & -0.014 & -0.012 \\
\hline 6 & $" \prime$ & 50 & 1.35 & $2.19 "$ & 22.3 & -0.166 & -0.005 & -0.038 & -0.012 \\
\hline 7 & $"$ & 10 & 1.28 & $4.50 \times 10^{-2}$ & 21.7 & -0.497 & -0.019 & -0.011 & -0.012 \\
\hline
\end{tabular}

となる. 図 8 に示した数值例に対して，式 (49)より 求めた差王比は，汪注 $k=2$ の場合に一致した。

\section{6. 結言}

オリフィス絞りの非定常特性を，自由流線がホドグ

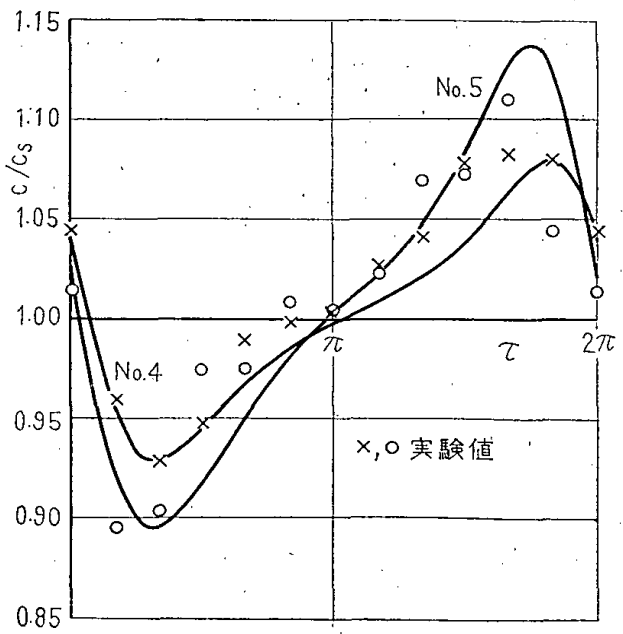

図. 16 理論と実験との比較（橓時流量係数比）

表 1. 実験条件 
表 2 理論と実験との比較

\begin{tabular}{|c|c|c|c|c|c|c|}
\hline \multirow{2}{*}{ No. } & \multicolumn{2}{|c|}{$\Delta \dot{\bar{p}}_{m} / \Delta \bar{p}_{s}$} & \multicolumn{2}{|c|}{$(\sqrt{\Delta \bar{\Delta}})_{m} / \sqrt{\Delta \bar{p}_{m}}$} & \multicolumn{2}{|c|}{$c_{m} / c_{s}$} \\
\hline & 理 論 & 实 験 & 理 論 & 実 戨 & 理 墖 & 実”験 \\
\hline 1 & $1: 066$ & 1.051 & 0.969 & 0.969 & 1.001 & 1.000 \\
\hline 2 & 1.028 & 1.009 & 0.986 & 0.984 & 1.000 & 1.010 \\
\hline 3 & 1.033 & 1.009 & 0.984 & 0.983 & 1.002 & 1.007 \\
\hline 4 & 1.076 & 1.042 & 0.963 & 0.965 & 1.003 & 1.014 \\
\hline 5 & 1.030 . & 1.022 & 0.983 & 0.985 & 1.008 & 1.008 \\
\hline 6 & 1.015 & 0.964 & 0.990 & 0.989 & 1.009 & 1.040 \\
\hline 7 & 1.124 & 1.127 & 0.942 & 0.947 & 1.007 & 0.998 \\
\hline
\end{tabular}

ラフ面に执いてだ円で与えられるとして解析し，それ を実験值と比較しつぎの結果を得た。

（1）縮流係数は，流量の增加区間では定常流の值 よりも大きくなり，減少区間では逆に小さくなる，正 弦波状の流量変動の場合, 縮流係数の平均值は, 定常流 の場合に比べてわずかではあるが，減少傾向を示す.

（2）瞬時の流量と差玨とから定義した瞬時流量係 数は，流量の增加区間では定常流の値より小さくな り，減少区間では逆に大きくなる，正弦波状の流量変 動の場合，瞬時流量係数は定常流の場合に比べわずか ではあるが，増加傾向を示す。

（3'）脈動流量の振幅比 0.5 以下，周波数 $50 \mathrm{~Hz}$ 以下に和ける実験結果は，理論值と良い一致を示し た.

（4）脈動流の平均流量の測定に括ける平方根誤
差および等価長さを用いたオリフィス非定常特性の 記述について検討し，これらの取扱いの妥当性を確か めた。

本実験に当たって，当時の本学学生 太田民男, 本 間 清, 浦島正行らの諸君の助力を得た。 な文部省 科学研究費 (総合研究, 代表者 名古屋大学 古屋善 正教授）の補助を得た。ここに記して謝意を表する。

\section{文献}

(1) Earles, S.W.E. and Zarles, J.M., Proc. Inst . Mech. Engr., 177-37 (1963), 997.

(2) Mottram, R.C. and Zarek, J.M., Symp. Meas. Pulsating Flow, (1970), 25, Inst. Meas. Contr.

(3) Sparks, C.R., Flow Meas. Symp., (1966), 124, ASME.

(4) Mosely, D.S., 文献 (3) の 103 ページ.

(5) Funk, J.E., ほか 2 名, Trans. ASME, Ser. D, 94-2 (1972-6), 483.

(6) Thurston, G:B, and Wood, J.K., J. Acous. Soc. Amer., 25-5 (1953), 861.

(7) Rayleigh, L., Theory of Sound, Vol. II (1940), 181, MacMillan.

(8) Schultz-Grunow, F., Forsch. Geb. Ing.-Wes., 12-3 (1941), 117.

(9) Birkhoff, G. and Zarantonello, E.H., Jets. Wakes, and Cavities, (1957), Chap. XI, Academic Press.

(10) Gurevich, M.I., Theory of Jets in Ideal Fluids, Chap. IX, (1965), Academic Press.

(11) Moody, F.J. and Reynolds, W.C., Trans. ASME, Ser. D, 94-3 (1972-9), 606

（12）藤本, 流体力学, (昭 32)，65, 羕賢堂, および文献（9）の Chap. II.

(13) Daily, J.W., ほか2 名, Trans. ASME, 78-5 (1956-7), 1071.

\section{討 論}

[質問] 松 永 成 徳 (九州工業大学)

オリフィスの非定常特性を自由流線理論により解 析, 縮流係数打よび流量係数の理論值, 実験值をえて 良好な結果がえられ與味深い，ただ理論は二次元，実 験は軸対称としたため，本研究の主旨がやや不めいり ょうになった感じをうける，つぎの事項について所見 を伺いたい。

（1）理論と実験との比較について．理諭で自由流 線の流速がホドグラフ上のだ円に写ると仮定し，近似 式 (28) 飞より式 (30)の $\alpha$ ，式 (31)の $\bar{H}$ を求めて いる. 式（28）の誤差が $\alpha, \bar{H}$ にどのように伝ぱする か不明なので，仮定の検証が困難にならないか.

（2）平方根誤差について. 図 12 の代わりに例兄 ば $k=0.1 ， \varepsilon=0.6$ で，かなり大きい $L \omega / U$ に対して 平方根誤差を計算し，自由流線特有の要素を明示しえ ないであろらか

（3）図 13 そついて。これは一般には差圧形流量
計における加速度の影響を時間平均し，流量の形で示 したものと解される。この図机执いて大きいにについ て解が求まらないのは，具体的にどうなるのか。

（4）実験装置について. 周波数 $30 \sim 50 \mathrm{~Hz}$ に和 いて，定在波の影響は無かったか.

（5）実験について，（a） $2 n-1$ 箇所の流速は同 時測定したか.していなければ流量の瞬時值測定精度 の低下が懸念される。

（b）表 1，No. 4 と 7 は同じ条件の実験と認めら れるが， $\varepsilon_{1}$ は互いに $30 \%$ 異なり， $\varepsilon_{3}, \varsigma_{4}$ でも補償しき れないように見觉るが原因は何か。

（c）表 2, No. 4, 7 は潘か比べて $\Delta \bar{p}_{m} / \Delta \bar{p}_{s}$ が 大きい。また No. 7 は4 に比べてさらに大きい。原 因は何か。

〔回答〕（1）最良近似であること，愦差の大き さが注ぼ等しいことを条件とすると，式 (28)，(29） 以外の近似は，実質的にとれないと考えられる．ただ 
この仮定は自由流線に対する境界条件と関連する、の で，境界条件の充足程度について検討した結果を付図 1,2 に示す. いずれも $\varepsilon=0.6, L \omega / U=0.1$ の場合 である. 付図 1 は式 (5) に対する検討結果であり，縦 軸は $D G / D \tau=(L \omega / U) \partial G / \partial \tau+\bar{u} \partial G / \partial \bar{x}+\bar{v} \partial G / \partial \bar{y}$ を,

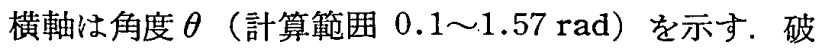
線は值が負であることを示す，誤差の判定には，自由 流線の方程式 (17)，（18）の形から $\bar{u}, \bar{v}$ の代表值 1.0 と $D G / D \tau$ を比較することが妥当であり， $D G / D \tau \fallingdotseq 0$ が満たされているといえる。な特 $\theta=1.57 \mathrm{rad} に$ ける $D G / D \tau$ の増大は， オリうィスのシャープェッジ に特いては式 (5)が適用されないためであり， $\theta=0$ $\operatorname{rad}$ 近傍に拉ける増大は $\theta=0$ が特異点であるためと 考えられる。

，付図 2 は式 (24)、に対する検討結果であり，縦軸は 式 (24) の左辺に $2 L \omega / U$ を乗じた值 $B$ を示す. 図

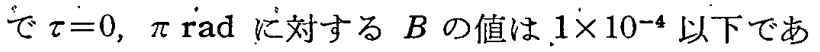

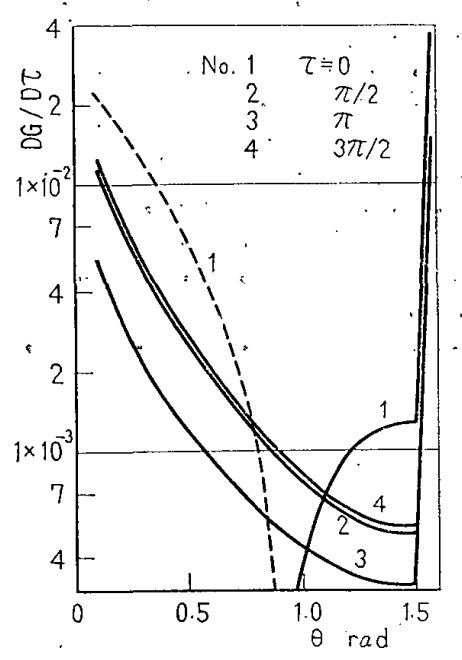

付図 1 式 (5)に対する誤差

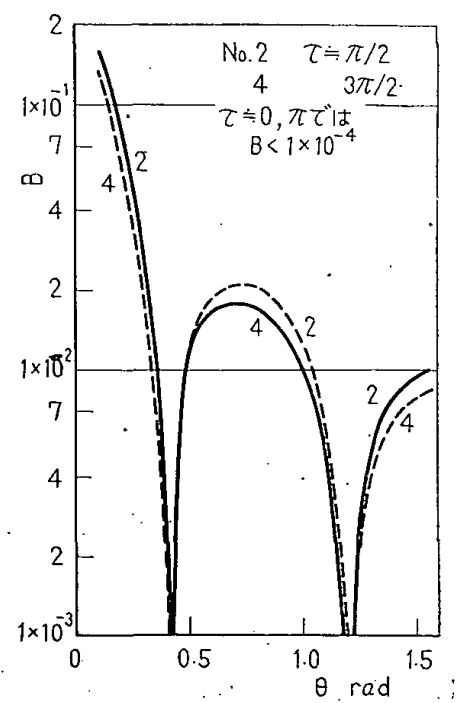

付図 2 式 (24) に対する誤差
る. 䛊差の判定には， $R$ の代表值 1.0 と $B$ とを比較 するのが妥当であり， $\theta=0 \mathrm{rad}$ の近傍で䛊差が大き いが他の部分ではほぼ満足すべき結果と考觉られる。

な扣ご指摘の点は，本報文に扣いて自由流線がホド グラフ面でだ円で与えられると仮定したためた生じる 問題であり，任意形状とすれば解の精度は高められる と思う。

(2) $\varepsilon=0.6, k=0.1$, について $\Delta \bar{p}_{m} / \Delta \bar{p}_{s}$ を求める と, $L \omega / U \leqq 0.001$ では $\Delta \bar{p}_{m} / \Delta \bar{p}_{s}=1.1800$ [式 (40) に一致], ストローハル数の増加につれて徐々に減少す る.しかしその割合は小さく, $L \omega / U=0.1$ で 1.1760 , ほ核計算可能な限界である $L \omega / U=0.11$ で 1.1751 . となる. $\varepsilon, k$ の值によって計算可能なストローハル数 の最大值は異なるが， その限界に拈いても $\Delta \bar{p}_{m} / \Delta \bar{p}_{s}$ の変化はこのようにわずかである.

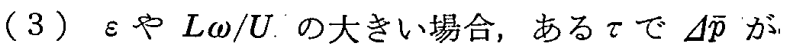
負値をとるようになり，図 12,13 は $\Delta \bar{p}>0$ の範团 について求めたものである.な拉 $\Delta \bar{p}<0$ の場合でも 式 (30) より $\alpha$ は求まる. しかし $\varepsilon や ~ L \omega / U$ をさら に大とすると，その実根は求まらない.

（4）脈動発生用空気生シリンダの駆動用サーボ弁 の入力電王の振幅を一定とし, その周波数を実験範囲 内で変えても, 圧力や流速の振幅に目立った変化は見 られなかった.このことから，管長と周波数の関係と， して共振状態が生ずるはずであるが，本装置ではその 程度は弱いものであると考えている.

(5) (a) 同時測定ではない，圧力波形を時間（位 相）の基準としている.

（b ），(c) 流量振幅の影響を示すため, 脈動発生用 空気圧シリンダの行程を変えた実験である. $\Delta \bar{p}_{m} / \Delta \bar{p}_{s}$ は図 12 に示すようにストローハル数の影響をほとん ぞ受けないが，流量振幅に対して二次曲線状に変化す る. したがって流量振幅の最大である No. 7 に抽い て $\Delta \bar{p}_{m} / \Delta \bar{p}_{s}$ が最大となっている.

[質問] 近江 宗一（大阪大学工学部）

自由流線理諭を用いて，絞りを通る非定常流に対 し，美圧と流量に関する特性を明確に示された点に敬 意を表す，必然的に非王縮性の場合となり，これも普 通の場合十分有效と思らが，下記の事項について質問 する.

(1). 式（36）より $\bar{q}=1-\varepsilon \cos \tau$ であるから， $\tau=$ $0, \varepsilon=0.4$ とした場合, 図 8 より $\Delta \bar{p} / \Delta \bar{p}_{s}=0.352$, ᄂ たがって式 (35) より $c / c_{s}=1.01$ となるが, 図 9 を みると $c / c_{s}=1.0$ のようにもみられる. 1.0 と巽なる 值でよいのか. その場合, 図 16 の理論と実験の比較 では, $\varepsilon=0.4$ に比較的近い場合の No. 4 に対して 
1.04 くらいの值をとっているが，この相違は波形の ひずみすなわち $\varepsilon_{2}, \varepsilon_{3}, \varepsilon_{4}$ の值に基因するるのか.

（2）流速測定には，I 形プローブで十分かと思う が，X形を使用されたのは，いかなる理由からか。

（3）微圧力変換器は，共振周波数 $500 \mathrm{~Hz}$ という ことで，実験状態での検定は省略されていると思う。 取付け状態の詳細，たとえば管壁面と受压面との間の. 通路の長さや形状などわからないが，No. 5 の $30 \mathrm{~Hz}$, No. 6 の $50 \mathrm{~Hz}$ などの場合には，応答が多少問題に なるとも考えられる. もし問題になるとすれば，図 15，16などに打いて影響が現れでくると思うがいかが か.

（4）図 16 に打りる理論値之奏験值の美異の原因 として，つぎの項目などを考えるが，どのように思わ れるか。

（i） 前記（3）項に述べた圧力測定の愦差.

（ii）軸対称流と考えられる現象を, 二次元流の理 論で比較されたこと。

（iii）流量に，理論ではをを用いて扣られるにもか かわらず，実験では $\varepsilon 2, \varepsilon_{8}, \varepsilon_{4}$ などで表されるひずみが 存在すること.

[回答].（1）因 8，9 k示卞理論計算結果では $\Delta \bar{p} / \Delta \bar{p}_{s}=0.3623 \quad(k=1) \sim 0.3617 \quad(k=4), \quad c / c_{s}=$ $0.9968(k=1) \sim 0.9975 （ k=4 ）$ となる. また実験 No. 4 亿対する理論值は $c / c_{s}=1.0378 \quad(k=1) \sim$ $1.0505(k=4)$ となる. 実験データの整理に扎いて は，圧力が最小值となる時間を $\tau=0$ と選んでいるた め, 数値例の場合と多少の位相差を生じて㧊り，ご指 摘の二つの場合に打ける差は $\varepsilon_{2} \sim \varepsilon_{4}$ の値に基因して いる.

（2）本報文には記していないが，実験としてはオ リフィス下流の速度分布の測定を予定し，第 1 段階と してオリフィス孔出口の速度分布（速度べクトルの分 布）をX形プローブを用いて測定した。

（3）管壁面と受圧面の間は付図 3 に示す構造とな っている.この管路系について仮定

（i）流れは層流であり，流体は断熱变化をする.

（ii）受圧面の変形は流体の圧縮量に比べ無視でき

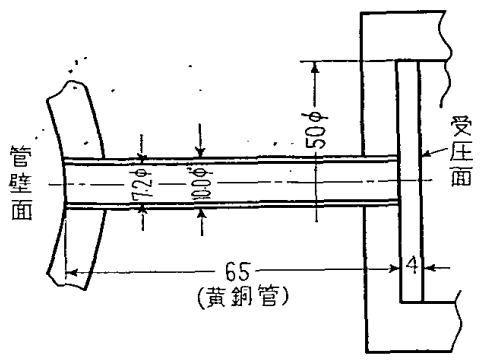

付図 3 微圧力変換器の取付け状態

る.

（iii） 流体の慣性と粘性は管路 1（内径 $7.2 \mathrm{~mm}$ ) に集中している.

（iv）流体の圧縮性は管路 2（内径 $50.0 \mathrm{~mm}$ ）飞集 中している，ただし流体体積は管路 1，2 の合計とす る.

の下に, $p_{2} / p_{1}\left(p_{2}\right.$ : 受圧面圧力, $p_{1}$ : 管壁面圧力 ) に ついての周波数伝達関数を求め, 数值を代入するとつ ぎの結果を得る。

$\begin{array}{lcc}\text { 振動数 } & \text { 振幅比 } & \text { 位 相 } \\ 30 \mathrm{~Hz} & 1.005 & -2.6 \times 10^{-4} \mathrm{rad} \\ 50 \mathrm{~Hz} & 1.015 & -4.4 \times 10^{-4} \mathrm{rad}\end{array}$

したがって図 15，16 亿示す 10 括よび $30 \mathrm{~Hz}$ の場合， 压力変換器の取付け方法による誤差は問題とならない と考兄られる。

（4）理論值と実験值との美異について，流量の測 定精度が最大の原因であると考えている．ご指摘の 3 項目についてはつぎのように考皇る。

（i ）については（3）を参照願いたい.

（ii）例えば，二次元の場合について実験を行わな いと明らかにならないが，定常流に対しては自由流線 理論による二次元オリフィス絞りの縮流俰数が軸対称 流の実験值とほぼ一致すること，非定常流でもその程 度があまり大きくない場合には，その影響もあまり大 きくないと考えられることから，本報文のよらな取扱 いが可能であると思う.

（iii）これらの比較において，流量飞 $\varepsilon_{2} \sim \varepsilon_{4}$ を含 めた理論值を求めている. 